\title{
Innovation as an Economic Driving Force in Australia
}

\author{
Ovais Vohra ${ }^{1}$ \\ 1 Business Management \& Foreign Trade Department, Istanbul Aydin University, Turkey \\ Correspondence: Ovais Vohra, Business Management \& Foreign Trade Department, Istanbul Aydin \\ University, Turkey. E-mail: ovaisvohra@yahoo.com
}

Received: October 15, 2017

doi:10.5539/ijbm.v13n1p13
Accepted: November 18, 2017

Online Published: December 20, 2017

URL: https://doi.org/10.5539/ijbm.v13n1p13

\begin{abstract}
Australia has vitally identified the benefits of innovation in past few years. The Country is ranked among the top nations in OECD. They are currently working on developing the infrastructure of Research and Development sector of the Country as well as reinforced themselves in developing their Information and Communication technology. Thus, the Country has identified the importance of innovation and how its components can help in achieving increased economic growth. Innovation is the inventive or new ways a company or country adopt to carry out its processes in a more efficient manner.

The incorporation of innovation in the processes of economic development through production or other ways lead to higher profitability and broader use of the available resources in an efficient and advanced way. Thus, the purpose of the following research is to analyze innovation as an economic driving force in Australia. For the fulfillment of this purpose, the researcher carried out a quantitative research under which 5-points Likert scale was designed that include questions relating to the various identified components of innovation as the independent variable and economic growth as the dependent variable. The survey was circulated among 219 executives that are working in different sectors of Australia to understand their opinion. The results through multi-regression model depicted that innovation and technology have a significant impact on the growth of Australian economy.
\end{abstract}

Keywords: Innovation, Economic Growth, Technology, ICT, Research and Development (R\&D), Skilled Labor and Productivity

\section{Introduction}

It is considered as a universally accepted statement that innovation is one of the most significant factors of long-term economic growth (Dodgson, Hughes, Foster, \& Metcalfe, 2011). More specifically, it is known that there have always been 3 most important production factors comprising land, labor, and capital, however, in recent time scholars and analyzers usually related these capabilities of producers with the informative factors (Pilat \& Lee, 2001). Thus, the industries in Australia and manufacturers now believe that along with the 3 production factors the information or innovation factor also play a very vital role in the growth of the economy (Foster, 2014).

Consequently, it is now been suggested that the traditional production factors should be utilized with the benefits of information and innovation factor by the manufacturers. Looking closely into the matter reveals that the traditional production factors; land, labor, and capital cannot alone assist in achieving long-term competitive sustainability. Most of the natural resources are not consistent enough to be reused or renewed and after a period of time, they become exhausted. Perhaps, the incorporation of innovation in production can open new opportunities and provide long-term sustainability and profitability to the businesses as well as the economy of Australia (Wong, Ho, \& Autio, 2005).

\subsection{Purpose}

The purpose of the following study is to analyze the key elements of innovation that work as the economic driving force in Australia.

\subsection{Research Questions}

1. Is there an impact of innovation on the growth of the economy of Australia?

2. Is there a significant effect of technology towards economic growth in Australia? 
3. Does skilled labor factor and productivity significantly affect the growth of the economy in Australia?

4. Do Information and Communication Technology have an impact on the economy of Australia?

5. Do Research and Development (R\&D) cause a significant impact on the growth of the economy of Australia?

\subsection{Outline}

The following study has five chapters in total. The first chapter discusses the fundamental objective of conducting the following study that is to find out the elements of innovation that assist in economic growth in Australia. The second chapter focuses on providing insight of formally surveyed literature on the following subject matter. The third chapter discloses all the methods utilized in collecting data, analyzing and completing the research. Further chapter four talks about the key findings and results of the analysis. The final chapter five will provide concluding statements, implications, and recommendations based on the results of the overall research.

\section{Literature Review}

\subsection{Understanding Innovation}

Innovation in the Economic sector as explained by (Eggink \& Elizabeth, 2011) is the creation and implementation of new techniques, new ways of producing and utilizing consumer goods, developing the manufacturing process in a way that delivers increased efficiency and productivity. According to Rosenberg (2004), innovation is the invention efforts of an organization to produce highly efficient ways of carrying out the production and other facilities. However, Roberts (2007) argues that every invention cannot be acclaimed as innovation. Rather they are those inventions that deliver a profit or simply innovation is the implementation of those ideas that yield revenue in return for the organization (Black \& Lynch, 2004).

\subsubsection{Open Innovation}

Academically, Open Innovation can be an efficient approach augmenting the organizational performance through the implementation of Innovation and technology. Organizational features, such as flexibility or a brief hierarchy, may signify their opportunities with the application of Open innovation. With the implementation of opening organizational boundaries, these businesses can access the essential harmonizing resources to deal with their scarce research and development (R\&D) capability or encompass end-users in their innovation procedure to cultivate marketing associated competence (Muzamil Naqshbandi \& Kaur, 2014).

Nevertheless, assuming scarcity of resources for any organization it is not as simple to execute open innovation as it may seem. Additionally, unsettling to the heterogeneity of open innovation, verdicts concerning to its implementation are a greater challenge yet an immense opportunity though organizations nowadays tend to focus more on this field. Open innovation is a model that undertakes an organization's effort towards utilizing their external concepts and internal notions, along with their internal and external routes to market, while incorporating developed research and technology (Marcet, 2008). Through open innovation, according to (Naqshbandi \& Naqshbandi, 2016) organizations, nowadays, are utilizing approaches with respects to information flows. Being very comprehensive, along with open innovation's novelty, subsidizes extreme focus on the ways to use it for processes. As (Enkel, Gassmann, \& Chesbrough, 2009) argue that the vagueness with the usage further constrains the structure of a comprehensible form of sustainability.

\subsection{Relationship of Innovation with Economic Growth in Australia}

The study by Bassanini, Scarpetta, \& Visco (2000) revealed that innovation has a highly significant impact on driving the economic performance of Australia. The Country has adopted multifactor productivity (MFP) through which the industries are able to deliver higher proficiency in the use of labor and capital (Gretton, Gali, \& Parham, 2004). Moreover, the implementation of Multifactor productivity (MFP) has been successful in developing the economy with the help of enhanced managerial practices, restructuring of the organization and, most significantly, to smarter and increased use of innovative ways in the process of manufacturing finished goods (Quiggin, 2001). Thus, explaining that innovation has a vital impact on the economic development that is why Australia is investing in improving its innovative techniques in production.

On the other hand, (Parham, Roberts, \& Sun, 2001) explains the relationship between innovation and economic growth by comprehending that the implementation of innovation capabilities has played a vital part in the growth dynamics and prosperity of the economy of Australia. The country has recognized that innovation is not merely relating to the utilization of technologies rather it has to be constructed early in the growth process with an aim to retain the learning capabilities and increase in overall productivity. (Gretton, Gali, \& Parham, 2004) 
highlighted that innovation in the Country also required addressing other economic challenges precisely in the local contexts, for instance, increasing literacy rate, eliminating diseases, unemployment and hunger as well as initiating extensive knowledge spreading throughout the Country to sustain return on investment in a form of well-shaped, highly skilled, and economically sustainable nation. Eventually, a fruitful growth strategy has to construct widespread innovation capabilities to foster growth in the Country (Dodgson, Hughes, Foster, \& Metcalfe, 2011).

\subsection{Technology}

Colecchia (2002) explained in their study that technology is the central force nowadays for the existence of a sustainable economy and thus it is of immense significance to Australia both currently and in future. However, (Diewert \& Lawrence, 2005) comprehended that Australia believes that technology has insight for the growth, application, and use of technologies and the Country believes in developing in this sector to attain long-term sustainability. Consequently, the research by (Costa, 2001) showed that growth and dispersion of new technology is the foremost source of Australia's manufacturing and economic growth, utilization, and productivity. Similarly, (Gretton, Gali, \& Parham, 2004) explained that new technology ascends through change - change in prevailing technologies and change in the process technology is formed, improved or used. Improving Australia's capability to lead and acclimatize to technological change can lead to considerable national profits.

\subsection{Skilled Labor and Productivity}

The labor force is one of the factors of production and it is somehow identified as the most important factor. Skilled labors lead to economic growth if they are utilized in an appropriate manner. The labor force learns, uses their capabilities and shares their knowledge (KPMG, 2016). Once they learn to use a technology or innovation they will attain greater skills which will in the long-run benefit the overall economy increasing the productivity internally as well as economically. Parham (2004) hypothesized that if it is skilled in labor formed that, by non-decreasing slight yields, generates growth without any external reason. Khoo, McDonald, Voigt-Graf \& Hugo (2007) demonstrated skilled labor delivering constant great returns on investment and extended valuable understandings into the substantial role of having a highly skilled workforce for long-term growth. Skilled workforce understands innovation and technology more efficiently thus increasing the productivity.

\subsection{Information and Communication Technology (ICT)}

Information and Communication Technology ICT are the most wide-ranging determinants of technologies. Australia tends to spend heavily on ICT to achieve very comprehensive impact across the Country's social, cultural, democratic, security and economic structures (Diewert \& Lawrence, 2005). ICT is a highly valuable resource of innovation through which greater positive changes are achieved in the economy. Thus, researchers believe that ICT is among the most significant components of innovation that lead to major growth in the economy (Colecchia, 2002).

\subsection{Research and Development $(R \& D)$}

Research and development are major driving innovation and domestic development and economic development, however, there also necessitate a greater investment of time, money, efforts and many other factors to be successful. $R \& D$ is that critical sector of an economy that delivers new techniques, and innovative ways to further carry out economic development. Nicolaides (2014) explained R\&D as "innovative work commenced in a methodical source in order to upsurge the stock of technology, information, and knowledge. When companies deliver resources for $R \& D$ they expect a return on their investment (ROI).

\section{Proposed Framework}

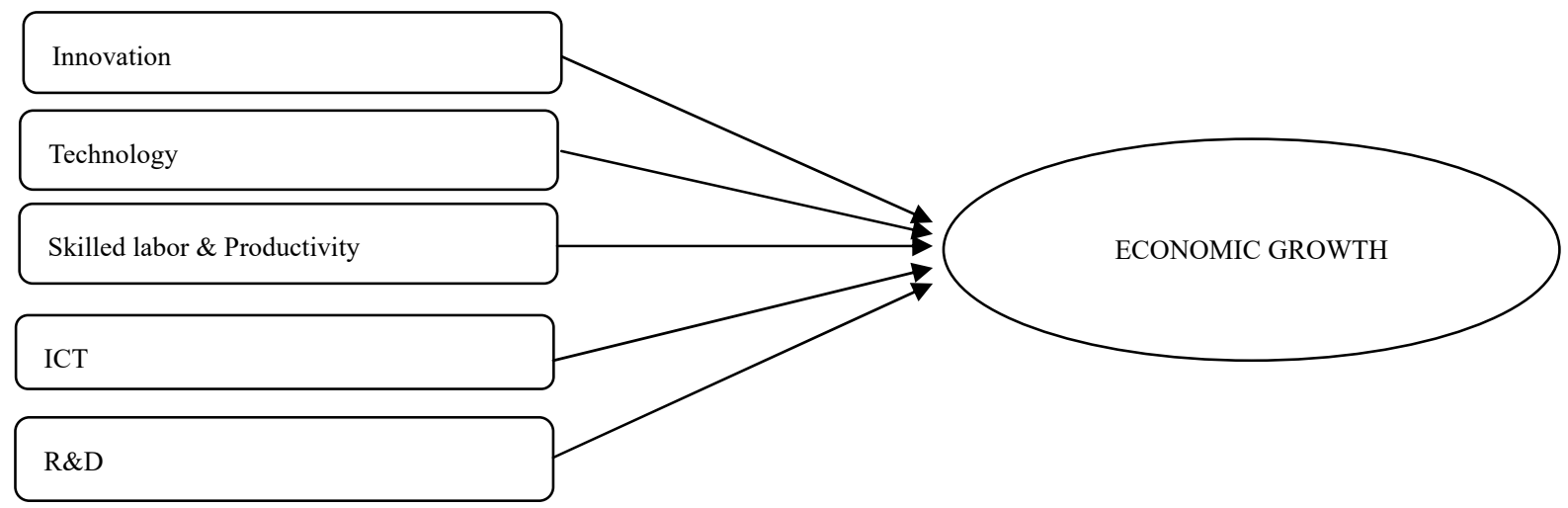




\section{Research Hypotheses}

H1: Innovation has a significant impact on economic growth of Australia.

$\mathrm{H} 2$ : Technology has a significant impact on economic growth of Australia.

H3: Skilled labor force and productivity have a significant impact on economic growth of Australia.

H4: Information and Communication Technology has a significant impact on economic growth of Australia.

H5: Research and Development (R\&D) have a significant impact on economic growth of Australia.

\section{Research Methodology}

\subsection{Data Collection and Analysis Techniques}

The following research has been completed under Post-positivism research philosophy as the study aims to understand how innovation drives the economy of Australia. In addition, the deductive approach was used because hypothesis was generated first by prior reviewing the literature and then data was collected using a probabilistic sampling method, specifically a stratified random sampling technique. Moreover, it is a quantitative research employed with realist ontology and objectivist epistemology.

The data was collected through primary data collection techniques under which research designed a five-point Likert-scale with questions relating to the adopted independent variables of the study. The five-point Likert scale questionnaire indicates values from 1 to 5 where ' 1 ' is equal to "strongly disagree" and ' 5 ' is equal to "strongly agree". Questionnaires were distributed among 219 randomly selected employees working in various different sectors and organizations to understand how they comprehend innovation and which components of innovation they believe are significant towards the growth of the economy in Australia. The independent variables adopted from prior studies and incorporated in this research are listed below.

Table 1. Adopted variables and Sources

\begin{tabular}{ll}
\hline Variable & Source \\
\hline 1. Innovation & (Eggink \& Elizabeth, 2011) \\
2. Technology & (Parham, Roberts, \& Sun, Information technology and Australia's productivity \\
& surge., 2001) \\
3. Skilled Labor force and Productivity & (KPMG, 2016) \\
4. Information and Communication Technology & (Gretton, Gali, \& Parham, 2004) \\
(ICT) & (Nicolaides, 2014) \\
5. Research and Development (R\&D) & \\
\hline
\end{tabular}

\section{Data Analysis}

The software which was used to analyze the data is SPSS (Statistical Package for Social Siciences).

\subsection{Multiple Regression Analysis}

It is that statistical tool which enables the analysis of multiple independent variables in relation to a single dependent variable (Norusis, 2006). Thus, in the following study, the following test has been run to analyze the relation of various independent variables that are the components of innovation with economic growth.

Table 2. Regression Analysis

\begin{tabular}{|c|c|c|c|c|c|c|c|c|c|c|}
\hline \multirow[b]{3}{*}{ Model } & \multirow[b]{3}{*}{$\mathrm{R}$} & \multirow[b]{3}{*}{ R Square } & \multirow[b]{3}{*}{$\begin{array}{l}\text { Adjusted R } \\
\text { Square }\end{array}$} & \multicolumn{6}{|c|}{ Model Summary ${ }^{b}$} & \multirow[b]{3}{*}{$\begin{array}{l}\text { Durbin- } \\
\text { Watson }\end{array}$} \\
\hline & & & & & \multicolumn{5}{|c|}{ Change Statistics } & \\
\hline & & & & $\begin{array}{l}\text { Std. Error of } \\
\text { the Estimate }\end{array}$ & $\begin{array}{l}\text { R Square } \\
\text { Change }\end{array}$ & F Change & df1 & $\mathrm{df} 2$ & Sig. F Change & \\
\hline 1 & $.385^{a}$ & .148 & 128 & 1.31300 & .148 & 7.391 & 5 & 213 & .000 & .970 \\
\hline
\end{tabular}

\subsection{Model Summary}

The Durbin-Watson test helped in analyzing the hypotheses to ensure that the residuals of a regression do not auto-correlated against another (Zeileis \& Hothorn, 2002). The value of this test ranges from 0 to 4 . A value that is close to 2 specifies no autocorrelation whereas the close to 0 signifies positive autocorrelation and the value 
that is close to 4 signify negative autocorrelation (Zeileis \& Hothorn, 2002).

In the following study, it is observed that the Durbin-Watson value is 0.970 that is almost closest to 1 signifying that there is fewer autocorrelation within the analysis of the variables because the value that is between 1 to 3 is identified to be appropriate for a study.

$\mathrm{R}$-square, on the other hand, is explained as a statistic that describes the amount of variance occurred within the relationship among two (or more) variables (Eisenhauer, 2003). The value of R-square in this particular study is 0.148 that makes $14.8 \%$ showing that this much amount of independent variables determine the factors of the dependent variable. The remaining $85.2 \%$ determine those particular factors which are not incorporated in this study.

Table 3. ANOVA

\begin{tabular}{|c|c|c|c|c|c|c|}
\hline \multicolumn{7}{|c|}{ ANOVA ${ }^{\circ}$} \\
\hline & & $\begin{array}{c}\text { Sum of } \\
\text { Squares }\end{array}$ & df & Mean Square & $\mathrm{F}$ & Sig. \\
\hline \multirow[t]{3}{*}{1} & Regression & 63.710 & 5 & 12.742 & 7.391 & $.000^{a}$ \\
\hline & Residual & 367.203 & 213 & 1.724 & & \\
\hline & Total & 430.913 & 218 & & & \\
\hline
\end{tabular}

ANOVA provides with the analysis of variances of two or more variables. Thus, here the significance value of the study is 0.00 and a value that is less than 0.05 is accepted to be significant. So, the study is significant and accepted.

Table 4. Coefficients

\begin{tabular}{|c|c|c|c|c|c|c|}
\hline \multicolumn{7}{|c|}{ Coefficients $^{a}$} \\
\hline \multirow{2}{*}{\multicolumn{2}{|c|}{ Model }} & \multicolumn{2}{|c|}{ Unstandardized Coefficients } & \multirow{2}{*}{$\begin{array}{c}\begin{array}{c}\text { Standardized } \\
\text { Coefficients }\end{array} \\
\text { Beta }\end{array}$} & \multirow[b]{2}{*}{$\mathrm{t}$} & \multirow[b]{2}{*}{ Sig. } \\
\hline & & $\mathrm{B}$ & Std. Error & & & \\
\hline \multirow[t]{6}{*}{1} & (Constant) & 1.461 & .867 & & 1.685 & .093 \\
\hline & Innovation & .362 & .123 & .194 & 2.944 & .004 \\
\hline & Technology & .387 & .124 & .205 & 3.134 & .002 \\
\hline & $\begin{array}{l}\text { Skilled Labor Force and } \\
\text { Productivity }\end{array}$ & .113 & .077 & .096 & 1.470 & .143 \\
\hline & $\begin{array}{l}\text { Information and } \\
\text { Communication } \\
\text { Technology }\end{array}$ & -.311 & .081 & -.250 & -3.821 & .000 \\
\hline & $\begin{array}{l}\text { Research and } \\
\text { Development (R\&D) }\end{array}$ & -.095 & .078 & -.078 & -1.209 & .228 \\
\hline
\end{tabular}

The above table provides with the coefficients and their respective significance value depicting that the variables comprising innovation, technology and Information and Communication technology have a "significance value" that is less than 0.05 which accepted which skilled labor force and productivity with R\&D are rejected showing insignificance.

\subsection{Hypotheses Result}

Table 5. Hypotheses

\begin{tabular}{|c|c|c|c|c|}
\hline & Hypothesis & Sig. & Result & $\begin{array}{l}\text { Gradient } \\
\text { (Beta, } \beta)\end{array}$ \\
\hline H1 & Innovation has a significant impact on economic growth of Australia. & 0.004 & Supported & 0.194 \\
\hline H2 & Technology has a significant impact on economic growth of Australia. & 0.002 & Supported & 0.205 \\
\hline H3 & $\begin{array}{l}\text { Skilled labor force and productivity have a significant impact on economic growth of } \\
\text { Australia. }\end{array}$ & 0.143 & $\begin{array}{l}\text { Not } \\
\text { Supported }\end{array}$ & 0.096 \\
\hline H4 & $\begin{array}{l}\text { Information and Communication Technology has a significant impact on economic growth of } \\
\text { Australia. }\end{array}$ & 0.000 & Supported & -0.250 \\
\hline H5 & Research and Development (R\&D) has a significant impact on economic growth of Australia. & 0.228 & $\begin{array}{l}\text { Not } \\
\text { Supported }\end{array}$ & -0.078 \\
\hline
\end{tabular}




\section{Discussion of Key Findings}

The following study sought to establish how innovation works as a driving force of Australian economy. The main purpose was to find out the components of innovation that has the significant impact towards the growth of the economy. Thus, researcher selected to examine 5 independent variables comprising Innovation, Technology, ICT, Research and Development (R\&D), and Skilled Labor and Productivity to find out how innovation is developing the economy of the nation.

According to the findings of the research, it is comprehensive that the major economic driving force in Australia tends to be innovation. However, the indispensable encounter of constructing an innovation-based system is the proficient use of advanced technology throughout the distinct processes of different organizations that will add-value to economic competitiveness. Similarly, the results have also shown that technology also plays a significant role in driving the growth of the economy and so Australian organizations believe that the implementation of technology has brought noteworthy changes in the process turning the workforce more skilled and high efficient generating increased productivity in each sector examined.

Even though it is believed that skilled labor force and R\&D causes increased changes in the development of the economy according to the review of the literature, nevertheless, this research has shown insignificancy with these factors. This can perhaps depict that the respondents trust open innovation, advanced technology along with information and communication technology more than other study factors. Future research can focus more on depicting better results for these factors.

To find this out the research developed a five-scale Likert questionnaire having 10 questions relating to the identified variables of the study and these questionnaires were randomly distributed among 219 respondents working in different organizations at various levels. The personal information of the respondents is kept completely confidential according to the demand of respondents. The responses of this survey were then tested through Multiple Regression Model of SPSS. The Durbin-Watson value of 0.970 shows that there is lesser auto-correlation among the variables of the study, however, the R-square is $14.8 \%$ indicating the level of the relationship between the independent and dependent variables.

Lastly, the ANOVA test helped in providing with the significance of each variable separately explaining that innovation with sig value of 0.004 , technology sig value of 0.002 and Information and Communication technology sig value of 0.00 are the significant variables and these are accepted for the study. On the other hand, the R\&D with a sig value of 0.228 and skilled labor and productivity with sig value of 0.143 are rejected in the study as they are insignificant according to the response results. The total sig value of the study is 0.00 indicating the research is significantly accepted. Thus, explaining that innovation and technology plays a significant role in the growth of Australian economy.

\subsection{Implications of the Study}

The study analyzing innovation as an economic driving force in Australia is useful for those who seek to learn about innovation. This is useful for researchers and future scholar in initiating future research based on this subject matter in a more globalized way. Moreover, this study is important for the economists, producers, and administration who seek understand the importance of innovation and technology towards increasing the economic system of the Country.

\subsection{Limitations of the Study}

- Severity to control, assesses, and validate the data was faced.

- The time-frame of the overall research was limited and the quantity of accumulated was time-consuming.

- Collection of data for the research was yet another time-consuming process limiting the authors towards greater presentation.

- The lack of resources constrained the authors to attain the data and information from only the available means.

- The non-serious respondents have cause partiality or inaccuracy in the results to some extent which can be reviewed by future researchers.

\subsection{Recommendations for Future Research}

$>$ The future research should further emphasize the importance of Research and Development as it is believed that $\mathrm{R} \& \mathrm{D}$ leads to the designing and incorporation of technology and innovation yet this research has not appropriately highlighted its importance based on the responses. 
$>\quad$ The future research should be based on a broader spectrum developing a broader questionnaire and targeting greater sample to understand the subject matter in a more comprehensive manner.

$>\quad$ The future researchers may also invest more time and resources in data collection and validation processes.

\section{Conclusion}

The following research has concluded that for the economy to remain sustainable it is important that they realize the significance of innovation. The results of the study have shown that people believe that innovation and technology are the driving the growth of the economy and Australia has been able to maintain a growth rate of approximately $2.1 \%$ from past few year mainly due to their efforts towards developing and implementing innovation in the production of goods and services. Thus, Australia has also introduction multifactor production where they incorporate innovative ways and new technology with the basic factor of productions to carry out the production function in an efficient manner. So, currently, the best resource Australia has to boost its economy is innovation and technology.

\section{Acknowledgements}

The research is conducted at Istanbul Aydin University. I would like to thanks with my heart \& soul to Istanbul Aydin University Business Management, Foreign Trade \& International department, I would like to thanks to Hamdard University Pakistan, Waqar Usmani Language Support centre Pakistan, Philip University Marburg Germany, NEO Group Pakistan, T.C Okan University Istanbul ,Canadian universities and last but not least, special thanks to Australian universities professors and other educational institutes for their kind support in to providing necessary data and co-supervise this research.

I delicate this research to my beloved parents and my teachers they make be able to do valuable contribution for Business World.

\section{References}

Bassanini, A., Scarpetta, S., \& Visco, I. (2000). Knowledge technology and economic growth: Recent evidence from OECD countries.

Black, S. E., \& Lynch, L. M. (2004). What's driving the new economy?: The benefits of workplace innovation. The Economic Journal.

Colecchia, A. (2002). ICT investment and economic growth in the 1990s: is the United States a unique case?: a comparative study of nine OECD countries. Review of Economic Dynamics, 408-442.

Costa, C. (2001). Information technology outsourcing in Australia: a literature review. Information Management \& Computer Security, 213-224.

Diewert, W. E., \& Lawrence, D. A. (2005). Estimating Aggregate Productivity Growth for Australia: The Role of Information and Communications Technology: an Occasional Economic Paper. Department of Communications, Information Technology and the Arts.

Dodgson, M., Hughes, A., Foster, J., \& Metcalfe, S. (2011). Systems thinking, market failure, and the development of innovation policy: The case of Australia. Research Policy, 1145-1156.

Eggink, \& Elizabeth, M. (2011). The Role of Innovation in Economic Development. The university of South Africa, 2(9), 5-9.

Eisenhauer, J. G. (2003). Regression through the origin. Teaching statistics, 76-80.

Enkel, E., Gassmann, O., \& Chesbrough, H. (2009). Open R\&D and open innovation: exploring the phenomenon. $R \& d$ Management, 311-316.

Foster, J. (2014). The Australian multi-factor productivity growth illusion. School of Economics, 16.

Gretton, P., Gali, J., \& Parham, D. (2004). The effects of ICTs and complementary innovations on Australian productivity growth. The economic impact of ICT: Measurement, evidence and implications, 105-130.

Khoo, S. E., McDonald, P., Voigt-Graf, C., \& Hugo, G. (2007). A global labor market: Factors motivating the sponsorship and temporary migration of skilled workers to Australia. International Migration Review, 480-510.

KPMG. (2016). The role of capital and labor in driving economic growth in Australia. KPMG Research Paper, 31. 
Marcet, X. (2008). Open innovation: A new paradigm. In Hybrid Intelligent Systems, 2008. HIS'08. Eighth International Conference on IEEE., pp. 959-960.

Muzamil Naqshbandi, M., \& Kaur, S. (2014). Do managerial ties support or stifle open innovation?. Industrial Management \& Data Systems, 652-675.

Naqshbandi, M. M., \& Naqshbandi, M. M. (2016). Managerial ties and open innovation: examining the role of absorptive capacity. Management Decision, 2256-2276.

Nicolaides, P. A. (2014). Research and Innovation - the drivers of economic development. African Journal of Hospitality, Tourism and Leisure, 16.

Norusis, M. J. (2006). SPSS 14.0 Guide to Data Analysis. Upper Saddle River, NJ: Prentice Hall.

Parham, D. (2004). Sources of Australia's productivity revival. Economic Record, 239-257.

Parham, D., Roberts, P., \& Sun, H. (2001). Information technology and Australia's productivity surge.

Pilat, D., \& Lee, F. C. (2001). Productivity Growth in ICT-producing and ICT-using Industries. OECD Science, Technology, and Industry Working Papers, 50.

Quiggin, J. (2001). The Australian productivity miracle: A skeptical view. Agenda: A Journal of Policy Analysis and Reform, 333-348.

Roberts, E. B. (2007). Managing invention and innovation. Research-Technology Management, 35-54.

Rosenberg, N. (2004). Innovation and Economic Growth. Innovation and Economic Growth.

Wong, P. K., Ho, Y. P., \& Autio, E. (2005). Entrepreneurship, innovation and economic growth: Evidence from GEM data. Small business economics, 335-350.

Zeileis, A., \& Hothorn, T. (2002). Diagnostic checking in regression relationships.

\section{Appendix}

\section{QUESTIONNAIRE FOR INNOVATION AS ECONOMIC DRIVING FORCE IN AUSTRALIA}

\begin{tabular}{|c|c|c|c|c|c|}
\hline \multicolumn{6}{|c|}{$\begin{array}{l}\text { Indicate your agreement or disagreement with the following statements with a 'tick mark' on the selected } \\
\text { scale. }\end{array}$} \\
\hline & $\begin{array}{l}\text { Strongly } \\
\text { Disagree }\end{array}$ & Disagree & $\begin{array}{l}\text { Neither } \\
\text { Agree } \\
\text { nor } \\
\text { Disagree }\end{array}$ & Agree & $\begin{array}{l}\text { Strongly } \\
\text { Agree }\end{array}$ \\
\hline $\begin{array}{l}\text { 1. Innovation hasplayed a critical role in developing the } \\
\text { oversll economy of Australis over past } 10 \text { yesrs. }\end{array}$ & 1 & 2 & 3 & 4 & 5 \\
\hline $\begin{array}{l}\text { 2. Technological innovation helps in assisting the factor } \\
\text { of productions comprising land. laborsnd capital in the } \\
\text { process of manufacturing. }\end{array}$ & 1 & 2 & 3 & 4 & 5 \\
\hline $\begin{array}{l}\text { 3. Technological innovgtion is crested in the resesrch } \\
\text { and development (R\&D) sectors using human capitsl } \\
\text { and the existing knowledgestook It is then used in the } \\
\text { production of finsl goods and lesds to permanent } \\
\text { increases in the growth rate of output. }\end{array}$ & 1 & 2 & 3 & 4 & 5 \\
\hline $\begin{array}{l}\text { 4. Is there a positive relation between technological } \\
\text { implementation and economic development in our } \\
\text { country? }\end{array}$ & 1 & 2 & 3 & 4 & 5 \\
\hline
\end{tabular}




\begin{tabular}{|c|c|c|c|c|c|}
\hline $\begin{array}{l}\text { 5. Compsnies are investing hesvily on the Resegrch } \\
\text { and Development sector in order to gain innovative } \\
\text { advantsges which simultaneously affect the oversll } \\
\text { productivity of the organization as well as affecting the } \\
\text { economy of the Country by incressing it. }\end{array}$ & 1 & 2 & 3 & 4 & 5 \\
\hline $\begin{array}{l}\text { 6. The number of skilled labor force has incressed } \\
\text { during the years ss innovation, R\&D, and technology } \\
\text { require labor force with higher cspsbilities and } \\
\text { knowledge. Thus, innovation has more labor are } \\
\text { lesrning new skills snd cspabilities to tackle innovgtion } \\
\text { resulting in grester economic development. }\end{array}$ & 1 & 2 & 3 & 4 & 5 \\
\hline
\end{tabular}

\begin{tabular}{|c|c|c|c|c|c|}
\hline $\begin{array}{l}\text { 7. The importance of innovation has been reinforced } \\
\text { both by globslization snd by rapid advances in new } \\
\text { technologies, notsbly ICTs, which have ensbled new } \\
\text { forms of competition and opened new markets for the } \\
\text { crestion snd delivery of innovative products and } \\
\text { services in the Australig. }\end{array}$ & 1 & 2 & 3 & 4 & 5 \\
\hline $\begin{array}{c}\text { 8. Do you believe that the efforts of innovation in an } \\
\text { organization help in incressing its total productivity } \\
\text { level? }\end{array}$ & 1 & 2 & 3 & 4 & 5 \\
\hline $\begin{array}{l}\text { 9. Knowledge, as embodied in human beings (as } \\
\text { "human capital") and in technology, is central to } \\
\text { economic development in Australis. }\end{array}$ & 1 & 2 & 3 & 4 & 5 \\
\hline $\begin{array}{l}\text { 10. Australia has experienced spproximstely } 2.5 \% \text { GDP } \\
\text { growth rate in past } 2 \text { years. Do you believe that } \\
\text { innovative developments, technology and skilled labor } \\
\text { force is driving the growth of the economy? }\end{array}$ & 1 & 2 & 3 & 4 & 5 \\
\hline
\end{tabular}

\section{Copyrights}

Copyright for this article is retained by the author(s), with first publication rights granted to the journal.

This is an open-access article distributed under the terms and conditions of the Creative Commons Attribution license (http://creativecommons.org/licenses/by/4.0/). 